\title{
Dental implants in patients treated with oral bisphosphonates. A bibliographic review
}

\author{
José-Ma Montoya-Carralero ${ }^{1}$, Pablo Parra-Mino ${ }^{2}$, Piedad Ramírez-Fernández ${ }^{3}$, Isabel M $^{\mathrm{a}}$ Morata-Murcia $^{4}$, \\ $M^{a}$ del Carmen Mompeán-Gambín ${ }^{5}$, José-Luis Calvo-Guirado ${ }^{6}$
}

${ }^{1}$ Doctor of Dentistry. Master's student of Integrated Dentistry: Implantology. Faculty of Medicine and Dentistry, Murcia University

${ }^{2}$ Associate Lecturer, Master's program in Integrated Dentistry: Implantology. Faculty of Medicine and Dentistry, Murcia University

${ }^{3}$ Dental Graduate. Master's student of Integrated Dentistry: Implantology. Faculty of Medicine and Dentistry, Murcia University

${ }^{4}$ Dental Graduate. Master in Orthodontics, University of Southern Mississippi, Institution of Spain

${ }^{5}$ Associate Lecturer in Integrated Adult Dentistry. Faculty of Medicine and Dentistry, Murcia University

${ }^{6}$ Senior Lecturer in Integrated Adult Dentistry. Director of Master's Program in Integrated Dentistry: Implantology. Faculty of Medicine and Dentistry, Murcia University

Correspondence:

Calle Alhambra, $5-5^{\circ} \mathrm{A}$

30204 Cartagena. Spain.

icuect@hotmail.com

Received: $23 / 11 / 2008$

Accepted: $30 / 07 / 2009$

Montoya-Carralero JM, Parra-Mino P, Ramírez-Fernández P, MorataMurcia IM, Mompeán-Gambín MC, Calvo-Guirado JL. Dental implants in patients treated with oral bisphosphonates: A bibliographic review. Med Oral Patol Oral Cir Bucal. 2010 Jan 1;15 (1):e65-9.

http://www.medicinaoral.com/medoralfree01/v15i1/medoralv15ilp65.pdf

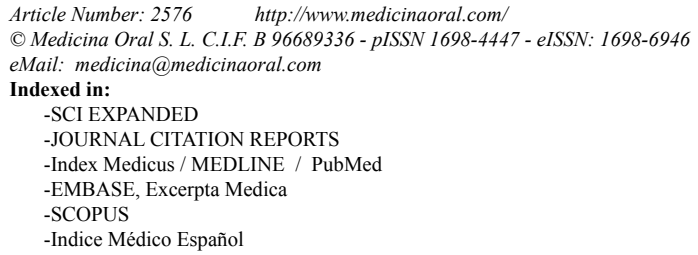

\begin{abstract}
Bisphosphonates inhibit bone resorption and are used to treat a range of pathologies, including Paget disease, osteoporosis, multiple myeloma and metastases associated with breast or prostate cancer. At present, there is no effective treatment for bisphosphonate induced osteonecrosis, so prevention is extremely important. Since quality of life deteriorates for those suffering osteonecrosis, maximum precautions should be taken with patients at risk, and especially whenever oral surgery, including dental implant placement, is contemplated. Dentists and oral or maxillofacial surgeons must keep up to date with the latest approaches to prevention, particularly when treating patients who are presently taking, or who will be taking bisphosphonates and are also candidates for dental implants.
\end{abstract}

Key words: Bisphosphonates, dental implants, osteonecrosis, maxilla.

\section{Introduction}

Bisphosphonates are a group of drugs that inhibit bone resorption. They act on osteoclasts, inhibiting chemotaxis, cutting osteoclast lifespan, slowing their activity and inducing apoptosis. There are important differences between bisphosphonates administered intravenously and those taken orally. Intravenous bisphosphonates are used to reduce bone pain, malignant hypercalcemia, skeletal complications suffered by patients with Paget's disease or myeloma and for the treatment of bone metastasis derived from various cancers (1). Oral bisphosphonates are used for the treatment of osteoporosis, Paget's disease and imperfect osteogenesis (Table 1). The nuclear structure of bisphosphonates consists of two phosphate groups joined by a single carbon atom (2). Bisphosphonates that include a nitrogen molecule in their bioactive structure are more powerful. They accumulate in maximum concentration in the osseous 
Table 1. Different types of bisphosphonate in current usage.

\begin{tabular}{|c|c|c|}
\hline Active ingredient & Trade name & Administered \\
\hline Alendronate & Fosamax $^{\circledR}$, Fosavance $^{\circledR}$ & Orally \\
\hline Etidronate & Osteum $^{\circledR}$, Difosfen $^{\circledR}$ & Orally \\
\hline Risedronate & Actonel $^{\circledR}$, Acrel $^{\circledR}$ & Orally \\
\hline Tiludronate & Skelid $^{\circledR}$ & Orally \\
\hline Zoledronate & Zometa $^{\circledR}$, Aclasta $^{\circledR}$ & Intravenously \\
\hline Pamidronate & $\begin{array}{c}\text { Aredia }^{\circledR}, \text { Linoten }^{\circledR} \\
\text { Pamifos }^{\circledR}, \text { Xinsidona }^{\circledR}\end{array}$ & Intravenously \\
\hline Ibandronate & Bondronat $^{\circledR}$ & Orally, Intravenously \\
\hline Clodronate & Bonefos $^{\circledR}$ & Orally, Intravenously \\
\hline
\end{tabular}

Table 2. Articles on implant placement in patients treated with bisphosphonates.

\begin{tabular}{|c|c|c|c|c|c|c|c|}
\hline AUTHORS & YEAR & PUBLICATION & SAMPLE & $\begin{array}{l}\text { N}^{0} \text { OF IM- } \\
\text { PLANTS }\end{array}$ & $\begin{array}{l}\text { BISPHOS- } \\
\text { PHONA- } \\
\text { TES } \\
\text { TAKEN } \\
\text { ORALLY }\end{array}$ & $\begin{array}{l}\text { IMPLANTS } \\
\text { LOST }\end{array}$ & $\begin{array}{c}\text { CASES OF } \\
\text { OSTEO- } \\
\text { NECROSIS }\end{array}$ \\
\hline $\begin{array}{l}\text { Marx et al. } \\
\text { (1) }\end{array}$ & 2005 & $\begin{array}{l}\text { J. Oral. Maxillo- } \\
\text { fac. Surg. }\end{array}$ & $\begin{array}{l}119 \text { cases of } \\
\text { osteonecrosis } \\
\text { in patients } \\
\text { treated with } \\
\text { oral bisphos- } \\
\text { phonates }\end{array}$ & Not stated & 3 & Not stated & $\begin{array}{l}4 \text { deriving from } \\
\text { implant placement }\end{array}$ \\
\hline $\begin{array}{l}\text { Jeffcoat } \\
\text { (13) }\end{array}$ & 2006 & $\begin{array}{c}\text { Int. J. Oral } \\
\text { Maxillofac. Im- } \\
\text { plants }\end{array}$ & 25 & 102 & $\begin{array}{c}25 \text { (for } 3 \pm 0.1 \\
\text { years on } \\
\text { average) }\end{array}$ & None & None \\
\hline $\begin{array}{l}\text { Wang et al. } \\
\text { (14) }\end{array}$ & 2007 & J. Periodontal & 1 & 5 & $\begin{array}{l}1 \text { (for more } \\
\text { than } 10 \\
\text { years) }\end{array}$ & None & 1 \\
\hline $\begin{array}{l}\text { Marx et al. } \\
\text { (15) }\end{array}$ & 2007 & $\begin{array}{l}\text { J. Oral Maxillo- } \\
\text { fac. Surg. }\end{array}$ & $\begin{array}{l}30 \text { cases of } \\
\text { osteonecrosis } \\
\text { in patients } \\
\text { treated with } \\
\text { oral bisphos- } \\
\text { phonates }\end{array}$ & Not stated & 30 & Not stated & $\begin{array}{l}2 \text { deriving from } \\
\text { implant placement }\end{array}$ \\
\hline $\begin{array}{l}\text { Fugazzotto } \\
\text { et al. } \\
\text { (12) }\end{array}$ & 2007 & J. Periodontal & 61 & 169 & $\begin{array}{c}61 \text { ( } 3,3 \text { years } \\
\text { on average })\end{array}$ & None & $\begin{array}{l}\text { Torus exposure } \\
\text { around one post- } \\
\text { extraction implant } \\
\text { which closed } \\
\text { spontaneously } \\
\text { after four weeks }\end{array}$ \\
\hline $\begin{array}{l}\text { Grant et al. } \\
\text { (10) }\end{array}$ & 2008 & $\begin{array}{l}\text { J. Oral Maxillo- } \\
\text { fac. Surg. }\end{array}$ & 115 & 468 & $\begin{array}{c}89 \\
\text { (33 for more } \\
\text { than } \\
3 \text { years) }\end{array}$ & 2 & None \\
\hline $\begin{array}{l}\text { Bell et al. } \\
\text { (11) }\end{array}$ & 2008 & $\begin{array}{l}\text { J. Oral Maxillo- } \\
\text { fac. Surg. }\end{array}$ & 42 & 101 & Not stated & 5 & None \\
\hline
\end{tabular}


matrix and in osteoclasts, mainly during the first 24-48 hours of medication. Concentration remains high over long periods.

In 2007, the American Association of Oral and Maxillofacial Surgeons defined osteonecrosis induced by bisphosphonates as the presence of unhealed exposed bone in the maxilla or mandible, persisting for more than eight weeks in patients who have taken systemic bisphosphonates but who have not received localized radiotherapy. In recent years maxillary cases of osteonecrosis following oral surgery, particularly exodontias, have been related to treatment with intravenous or oral bisphosphonates. The main intravenous bisphosphonates implicated are Pamidronate (Aredia ${ }^{\circledR}$ ) and Zoledronate (Zometa ${ }^{\circledR}$ ). Cases of osteonecrosis induced by oral bisphosphonates have also been recorded, although less frequently, particularly Alendronate (Fosamax ${ }^{\circledR}$ ) and Risedronate (Actonel ${ }^{\circledR}$ or Acrel $\AA$ ).

Marx et al. (1) claim that for patients taking bisphosphonates, osteonecrosis seems to be related to a lack of vascular supply in combination with a lack of bone remodeling and regeneration. Other factors which seem to influence the occurrence of osteonecrosis in maxillary structures (but not in other osseous structures) are that the maxilla receives an increased blood supply and shows faster osseous remodeling due to the everyday masticatory action of the teeth. Two other relevant factors may be that mandibular arteries are terminal arteries and that there are a large number of pathologies of dental origin that require dental treatments that then have repercussions for maxillary and mandibular bone.

\section{Materials and Methods}

A bibliographic search was carried out using Pub-Med ending in October, 2008. The search terms used were: oral bisphosphonates, dental implants, osteonecrosis, maxillary/maxilla.

The objective of this article was to produce an updated bibliographic review of dental implants in patients undergoing treatment with oral bisphosphonates.

\section{Results}

Since 2003, when Marx (4) published a series of thirtysix cases of osteonecrosis associated with bisphosphonates, numerous studies have been carried out which relate the occurrence of osteonecrosis in maxillary structures, mainly the mandible, associated with intravenous bisphosphonates following oral surgery, mainly exodontias (1, 4-9).

However, the topic of the present review is the incidence of osteonecrosis related to dental implant placement in patients undergoing treatment with oral bisphosphonates; our findings are shown in table 2.

\section{Discussion}

Administering bisphosphonates orally to post-menopausal women for the treatment of osteoporosis is fairly frequent nowadays. Nevertheless, the literature includes only a small number of cases of maxillary osteonecrosis following surgery in the buccal cavity of patients taking oral bisphosphonates $(1,7)$. The length of treatment with these drugs would appear to be a relevant factor, as the cases of osteonecrosis described occur in patients taking the drug for more than three years. Grant et al. (10) have described a series of 115 cases, of which eightynine took bisphosphonates orally prior to implant surgery and thirty-three of them for more than three years. No cases of osteonecrosis appeared and there were only two implants that failed to osseointegrate; of these, one patient had taken oral bisphosphonates for four years preceding surgery. Of the 115 patients, thirty-two of them were given sinus lifts, and six of these patients were on bisphosphonates for more than three years prior to surgery. Bell et al. obtained similar results published in an article that describes a series of 101 implants in forty-two patients; not a single case of osteonecrosis occurred but five implants failed in five different patients. Three of these five patients had taken bisphosphonates for more than three years. Nevertheless, four of these patients had received other implants at the same time which osseointegrated successfully. Of sixty-eight bone grafts carried out, there was only one failure.

Of the sixty-one patients treated with 169 implants by Fugazzotto et al. (12) with an average bisphosphonate medication period of 3.3 years, there was one case of bone exposure of the torus around a post-extraction implant, which closed spontaneously after four weeks. Jeffcoat (13) found that, of 102 implants in patients taking bisphosphonates over periods ranging between one and four years (average $3 \pm 0.1$ years) before surgery, not a single implant was lost. There was no occurrence of osteonecrosis and no significant differences were found when results were compared with a control group who did not take the drug. Nevertheless, Wang et al. (14) published a case of five mandibular implants in a patient who had been taking alendronate orally for over ten years, producing an osseous defect with necrosis around one of the implants six weeks after surgery; Marx et al. (15) also found two cases of osteonecrosis resulting from implant surgery in patients who had taken bisphosphonates orally over periods of more than three years. Recommendations published by the American Dental Association (16) warn that the placement of dental implants or guided bone regeneration involves an increased risk of osteonecrosis in patients undergoing treatment with oral bisphosphonates. Gomez et al. (17) state that generally, given the lack of research and the controversy surrounding dental implants for these patients, it is better to avoid them altogether along with all other types of 
oral surgery; Minguez-Serra et al. also propose avoiding surgery except in cases of absolute necessity. Bagán et al. (18) have published a series of recommendations for the prevention of osteonecrosis for patients with cancer who take bisphosphonates intravenously. The Spanish Society of Oral and Maxillofacial Surgeons elected a committee of scientists to produce a consensus document (19) on diagnosis, prevention and treatment of maxillary osteonecrosis induced by bisphosphonates. The American Association of Oral and Maxillofacial Surgeons do not contraindicate dental implant placement in patients who have been taking bisphosphonates orally for under three years prior to surgery providing they do not present other risk factors such as medication with corticosteroids or advanced age (over seventy years). After three years treatment with the drug it would appear advisable to cease medication for a minimum of three months before carrying out any kind of surgical intervention in the oral cavity after which the drug can be administered again once the surgery has completely healed. In the case of dental implants, a minimum of three months after surgery is recommended before the medication can be administered again. However, in the literature reviewed, most texts described implant placement in patients who had taken bisphosphonates orally for more than three years without any cases of osteonecrosis occurring, with the exception of a single case in which necrosis around two implants was observed radiologically and the two cases described by Marx et al. (15). In these retrospective studies, the patients who had been receiving the medication for over three years did not stop taking it, probably because they were treated before the findings of these panels of experts were published.

Marx et al. (15) recommend a blood test, the serum Cterminal telopeptide test (CTX) on an empty stomach, in order to evaluate the risk of osteonecrosis in patients who have been administered bisphosphonates for longer than three years. Values obtained that are greater than $150 \mathrm{pg} / \mathrm{mL}$ permit any kind of surgery to be performed with minimum risk and without needing to suspend medication. When values lower than $150 \mathrm{pg} / \mathrm{mL}$ are obtained, then medication should cease for a period of between four and six months or an alternative treatment option involving other types of prosthesis should be sought. Nevertheless, Bágan et al. (20) did not find a significant relation between this test and the number of exposed osseous areas or the size of necrotic areas in cancer patients treated intravenously with bisphosphonates.

\section{Conclusions}

It is necessary to carry out a greater number of longitudinal studies of implant placement in patients taking bisphosphonates orally in order to determine the safety of this procedure for this group of patients. More scientific evidence is also required in order to validate CTX testing as a technique for the prevention of osteonecrosis for these patients and therefore the introduction or nonintroduction of this test into pre-surgical protocols.

\section{References}

1. Marx RE, Sawatari Y, Fortin M, Broumand V. Bisphosphonateinduced exposed bone (osteonecrosis/osteopetrosis) of the jaws: risk factors, recognition, prevention, and treatment. J Oral Maxillofac Surg. 2005;63:1567-75.

2. Serra MP, Llorca CS, Donat FJ. Oral implants in patients receiving bisphosphonates: a review and update. Med Oral Patol Oral Cir Bucal. 2008;13:E755-60.

3. Advisory Task Force on Bisphosphonate-Related Ostenonecrosis of the Jaws, American Association of Oral and Maxillofacial Surgeons. American Association of Oral and Maxillofacial Surgeons position paper on bisphosphonate-related osteonecrosis of the jaws. J Oral Maxillofac Surg. 2007;65:369-76.

4. Marx RE. Pamidronate (Aredia) and zoledronate (Zometa) induced avascular necrosis of the jaws: a growing epidemic. J Oral Maxillofac Surg. 2003;61:1115-7.

5. Statz TA, Guthmiller JM, Humbert LA, Johnson GK. Intravenous bisphosphonate-associated osteonecrosis of the jaw. J Periodontol. 2007;78:2203-8.

6. Bagan JV, Murillo J, Jimenez Y, Poveda R, Milian MA, Sanchis $\mathrm{JM}$, et al. Avascular jaw osteonecrosis in association with cancer chemotherapy: series of 10 cases. J Oral Pathol Med. 2005;34:120-3. 7. Ruggiero SL, Mehrotra B, Rosenberg TJ, Engroff SL. Osteonecrosis of the jaws associated with the use of bisphosphonates: a review of 63 cases. J Oral Maxillofac Surg. 2004;62:527-34.

8. Infante Cossío P, Cabezas Macián A, Pérez Ceballos JL, Palomino Nicas J, Gutiérrez Pérez JL. Bisphosphonate-related osteonecrosis of the jaw in patients with multiple myeloma. Med Oral Patol Oral Cir Bucal. 2008;13:E52-7.

9. Wilkinson GS, Kuo YF, Freeman JL, Goodwin JS. Intravenous bisphosphonate therapy and inflammatory conditions or surgery of the jaw: a population-based analysis. J Natl Cancer Inst. 2007;99:101624.

10, Grant BT, Amenedo C, Freeman K, Kraut RA. Outcomes of placing dental implants in patients taking oral bisphosphonates: a review of 115 cases. J Oral Maxillofac Surg. 2008;66:223-30.

11. Bell BM, Bell RE. Oral bisphosphonates and dental implants: a retrospective study. J Oral Maxillofac Surg. 2008;66:1022-4.

12. Fugazzotto PA, Lightfoot WS, Jaffin R, Kumar A. Implant placement with or without simultaneous tooth extraction in patients taking oral bisphosphonates: postoperative healing, early follow-up, and the incidence of complications in two private practices. J Periodontol. 2007;78:1664-9.

13. Jeffcoat MK. Safety of oral bisphosphonates: controlled studies on alveolar bone. Int J Oral Maxillofac Implants. 2006;21:349-53.

14. Wang HL, Weber D, McCauley LK. Effect of long-term oral bisphosphonates on implant wound healing: literature review and a case report. J Periodontol. 2007;78:584-94.

15. Marx RE, Cillo JE Jr, Ulloa JJ. Oral bisphosphonate-induced osteonecrosis: risk factors, prediction of risk using serum CTX testing, prevention, and treatment. J Oral Maxillofac Surg. 2007;65:2397410 .

16. American Dental Association Council on Scientific Affairs. Dental management of patients receiving oral bisphosphonate therapy: expert panel recommendations. J Am Dent Assoc. 2006;137:114450.

17. Gómez Font R, Martínez García ML, Olmos Martínez JM. Osteochemonecrosis of the jaws due to bisphosphonate treatments. Update. Med Oral Patol Oral Cir Bucal. 2008;13:E318-24.

18. Bagán JV, Diz-Dios P, Gallego L, Infante-Cossío P, Jiménez Y, Junquera LM et al. Recomendaciones para la prevención de la os- 
teonecrosis de los maxilares (ONM) en pacientes con cáncer tratados con bisfosfonatos intravenosos. Med Oral Patol Oral Cir Bucal. 2008;13 Supl 3:161-7.

19. Sociedad Española de Cirugía Oral y Maxilofacial. Documentos. Diagnóstico, prevención y tratamiento de la osteonecrosis de los maxilares por bisfosfonatos. Recomendaciones de la Sociedad Española de Cirugía Oral y Maxilofacial.[citado 20 Sep 2008]. Available at:http://www.secom.org/ViewNoticiaClient.aspx?Id=450.

20. Bagan JV, Jiménez Y, Gómez D, Sirera R, Poveda R, Scully C. Collagen telopeptide (serum CTX) and its relationship with the size and number of lesions in osteonecrosis of the jaws in cancer patients on intravenous bisphosphonates. Oral Oncol. 2008;44:1088-9. 